\title{
Astyanax scabripinnis (PISCES: CHARACIDAE) HEMOGLOBINS: STRUCTURE AND FUNCTION
}

\author{
LANDINI, G. F., SCHWANTES, A. R. and SCHWANTES, M. L. B. \\ Universidade Federal de São Carlos, Departamento de Genética e Evolução, C. P. 676, \\ CEP 13560-950, São Carlos, SP, Brazil \\ Correspondence to: Gustavo Fraga Landini, Universidade Federal de São Carlos, Departamento de Genética e \\ Evolução, C. P. 676, CEP 13560-950, São Carlos, SP, Brazil, e-mail: gustavo_fraga@yahoo.com.br \\ Received October 25, 2001 - Accepted April 3, 2002 - Distributed November 30, 2002
}

(With 3 figures)

\begin{abstract}
Electrophoretic patterns of hemoglobins, Root effect, Bohr effect in blood and stripped hemoglobin, Hb$\mathrm{O}_{2}$ affinity GTP modulation of Astyanax scabripinnis (lambari), caught at three different altitudes in Ribeirão Grande, near Campos do Jordão (São Paulo), are described. All populations showed the same electrophoretic patterns: two cathodal components in starch gel. Normal Bohr effect values were found in these three populations both in blood $(\phi=-0,11)$ and stripped hemoglobin $(\phi=-0,12)$. Different blood $\mathrm{O}_{2}$ affinities collected in fish of these 3 populations were detected. GTP has a large influence on $\mathrm{Hb}-\mathrm{O}_{2}$ binding properties in A. scabripinnis. Stripped hemoglobin shows small Root effect. The addition of triphosphated nucleotides increases this effect. GTP is more effective than ATP on enhancing Root effect. Oxygen availability in water can be the factor responsible for differences found in blood $\mathrm{O}_{2}$ affinity.
\end{abstract}

Key words: lambari, oxygen availability, organic phosphates, Bohr effect, altitude.

\section{RESUMO}

\section{Hemoglobinas de Astyanax sacabripinis (Pisces: Characidae): estrutura e função}

Padrão eletroforético de hemoglobina, efeito Root, efeito Bohr em sangue e em $\mathrm{Hb}$ stripped e efeito do GTP na afinidade $\mathrm{Hb}-\mathrm{O}_{2}$ de Astyanax scabripinnis (lambari) coletados em três altitudes diferentes no Ribeirão Grande, na região de Campos do Jordão (São Paulo), são descritos. Todas as populações mostraram os mesmos padrões eletroforéticos: dois componentes catódicos em gel de amido. Efeito Bohr normal foi encontrado para as três populações, tanto em sangue $(\phi=-0,11)$ quanto em Hb stripped $(\phi=-0,12)$. Detectamos afinidades diferentes da hemoglobina ao $\mathrm{O}_{2}$ entre as três populações estudadas. GTP possui forte influência nas propriedades de ligação da hemoglobina ao oxigênio em Astyanax scabripinnis. Em hemoglobina stripped, o efeito Root é baixo. A adição de nucleotídeos trifosfatados aumenta esse efeito. GTP é mais efetivo que ATP no aumento desse efeito. A disponibilidade de $\mathrm{O}_{2}$ na água pode ser o fator responsável pelas diferenças encontradas nas afinidades da hemoglobina pelo oxigênio.

Palavras-chave: lambari, disponibilidade de oxigênio, fosfato orgânico, efeito Bohr, altitude.

\section{INTRODUCTION}

Hemoglobins are particularly important in studies of fish adaptations because the hemoglobin molecule is poised between the metabolism of the organism and the environment and so it has to cope with both metabolic requirements and environmental constraints (Riggs, 1979).
The Astyanax scabripinnis individuals studied here, live in river headwater, and in mountains, forming separated populations that are able to migrate down, but very seldom to it.

Krogh \& Leitch (1911) showed that blood respiratory properties could be related to availability of environmental oxygen. After this report, many authors showed that differences exist in 
functional properties of hemoglobin in fishes from different environments.

The present paper compares functional properties of unfractionated blood, hemoglobin electrophoretic pattern, functional properties of stripped hemoglobin and the influence of organic phosphates in $\mathrm{O}_{2}$ affinities, from three populations living at three different altitudes of Astyanax scabripinnis in Campos do Jordão, SP, Brazil.

\section{MATERIAL AND METHODS}

Seventy two Astyanax scabripinnis individuals caught at ponds located at three altitudes of Ribeirão Grande were analyzed: 29 specimens from 1,920 m, 26 from $1,800 \mathrm{~m}$ and 17 from $700 \mathrm{~m}$.

Blood was obtained by caudal puncture with heparinized syringes.

While still in the field just after bleeding a suspension of unfractionated blood and yeast in a buffered solution (bis-tris and tris $0.1 \mathrm{M}$ ) was placed in a YSI Oxygen Monitor (model 53) and the $\mathrm{O}_{2}$ consumption was plotted by a recorder. Oxygen dissociation was determined at $20^{\circ} \mathrm{C}$ as described by Johansen et al. (1978a). The Bohr factor $(\Delta \log \mathrm{P} 50 / \Delta \mathrm{pH})$ was calculated from oxygen dissociation curves obtained at different $\mathrm{pH}$ values.

The red blood cells were washed 3 times with $0.9 \% \mathrm{NaCl}$, and then tris-EDTA $0.015 \mathrm{M}, \mathrm{pH} 8.0$ was added to the packed erythrocytes in a $2: 1$ ratio. Hemolysis was achieved by freezing and thawing three times. To free the hemolysate of cellular debris, the sample was centrifuged at $12,000 \mathrm{~g}$ for $15 \mathrm{~min}$ at $4^{\circ} \mathrm{C}$.

The hemoglobin solution was frozen at $-20^{\circ} \mathrm{C}$ for further analysis in the laboratory.

In order to check if some variation was present in the samples, electrophoresis of individual hemolysates was carried out on starch gel as described by Smithies $(1955,1959)$ and modified by Val et al. (1981).

For spectrophotometric oxygen equilibria and Root effect experiments, the supernatant was then stripped of salt and organic phosphates by passage through a $2.5 \mathrm{~cm} \times 30 \mathrm{~cm}$ column of Sephadex G25 resin equilibrated in $0.1 \mathrm{mM}$ Tris- $\mathrm{HCl}, \mathrm{pH} 8.0$. Methemoglobin, when present, was reduced with dithionite in a Sephadex G-25 column according to Schwantes et al. (1976), modified in the following way: the sample was applied only after no dithionite solution remained at the top of the resin; due to change in the sample colors, reduction and reoxygenation could be accompanied visually as the sample passes through the column.

Oxygen equilibria of stripped hemoglobin were carried out at $20^{\circ} \mathrm{C}$ by the spectrophotometric method described by Riggs \& Wolbach (1956). The effect of GTP was measured by addition of appropriate volumes of solutions of ATP dissodium salt to stripped hemoglobin solutions. GTP was tested in a molar ratio of 1:8 (Hb: NTP). The P50, Bohr effect and $n$ values (Hill plot) were interpolated from linearized logarithmic plots of the $\mathrm{O}_{2}$ equilibrium data.

The Root effect was performed as described by Farmer et al. (1979) and the data were divided into four arbitrary categories based on approximate percentages: 0 , less than $10 \%$ deoxygenation; +, $10 \%-20 \%$ deoxygenation;,$++ 20 \%-40 \%$ deoxygenation; +++ , more than $40 \%$ deoxygenation. The amount of GTP and ATP used in these experiments was calculated as described above for GTP.

\section{RESULTS}

The hemolysates from several adult individuals were characterized eletrophoretically. The analysis of 20 specimens (not all samples could be submitted to electrophoresis due to the very low amount of blood obtained) showed two hemoglobins components, one major and another minor band. This pattern was constant from one individual to another (Fig. 1).

Oxygen equilibria determined from unfractionated blood samples of Astyanax scabripinnis are shown in Fig. 2. The results obtained from blood for $A$. scabrippinis at the three studied altitudes showed normal Bohr effect, with increasing $\mathrm{O}_{2}$ affinity in more alkaline $\mathrm{pHs}$. Little difference in oxygen affinities from blood samples from fish caught in any of these three altitudes were found. However the higher the altitude, the lower the affinity (Table 1).

The oxygen equilibria data on stripped hemoglobin, Bohr effect value was $\phi=-0.10$ and GTP presence increased slightly this effect, resulting in $\phi=-0.14$ (Fig. 3). Cooperativity values (n) for the Astyanax scabripinnis were approximately 1.0, showing low or no cooperativity, with or without GTP. 


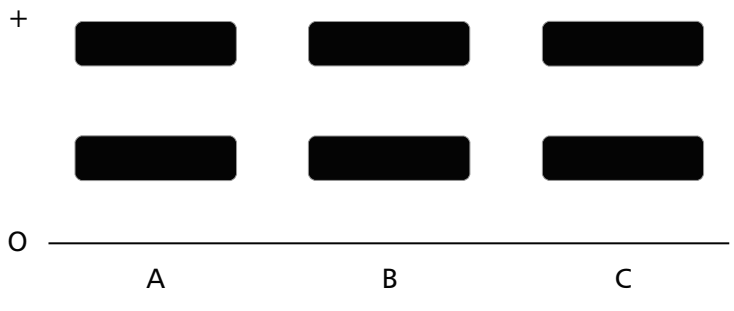

Fig. 1 - Diagrammatic representation of the electrophoretic patterns of unfractionated hemolysate of Astyanax scabripinnis on starch gel electrophoresis. A. Fish caught at 1,920 m; B. 1,800 m; C. 700 m.

TABLE 1

Unfractioned blood, $\mathrm{Hb}$ functional properties, temperature and $\mathrm{O}_{2}$ available in water at three altitudes.

\begin{tabular}{|l|c|c|c|}
\hline & $\mathbf{7 0 0} \mathbf{~ m}$ & $\mathbf{1 , 8 0 0 ~} \mathbf{~}$ & $\mathbf{1 , 9 2 0 ~} \mathbf{~ m}$ \\
\hline $\begin{array}{l}\text { Unfractioned blood } \\
\text { Bohr effect }\end{array}$ & -0.11 & -0.10 & -0.11 \\
\hline Log P50 $(\mathrm{pH} 7.0)$ & 1.12 & 1.2 & 1.31 \\
\hline Water temperature $\left({ }^{\circ} \mathrm{C}\right)$ & 21 & 18 & 16 \\
\hline Oxygen available $(\mathrm{mg} / \mathrm{L})$ & 9.5 & 10.2 & 10.4 \\
\hline
\end{tabular}

The Root effect analysis shows that ATP also modulates negatively $\mathrm{Hb}-\mathrm{O}_{2}$ affinity, but at a lower intensity than GTP (Table 2).

\section{DISCUSSION}

Electrophoresis is usually used in structural pattern characterizations of fish hemoglobins, i.e. number of components and relative concentrations. The support and system of buffers used varies and the choice of electrophoretic migration media depends on resolution power, costs, and speed, among other factors.

In this work, we used starch gel as a migration media for determining species electrophoretic patterns due to excellent resolution of this support for fish hemoglobin. Beside the samples obtained at the sites mentioned here, A. scabripinnis hemoglobin from other sites in the Campos do Jordão area were submitted to electrophoresis and showed an identical pattern. So this species is probably monomorphic for hemoglobin.

For the analyzed species, we observed that GTP decreases $\mathrm{Hb}-\mathrm{O}_{2}$ affinity showing that this phosphate acts negatively on $\mathrm{Hb}-\mathrm{O}_{2}$ affinity, and confirming the fact that GTP is the main modulator in fresh water fishes. These phosphates exert the greatest effect on P50 at $10 \mathrm{mM}$ concentration and GTP seems to depress oxygen affinities more strongly than ATP at the same concentration (seen in Root effect experiments). The Root effect analysis shows that ATP also modulates negatively $\mathrm{Hb}-\mathrm{O}_{2}$ affinity, but less intensely than GTP does. According to Weber et al. (1979), the concentration of GTP decreases more than ATP during hypoxia. Probably this happens with Astyanax scabripinnis too, since GTP is more effective than ATP as a negative modulator.

Studies of blood functional properties can be of the great value in understanding fish habitat and habits (Wood \& Johansen, 1972; Powers, 1974; Greaney \& Powers, 1978; Val et al., 1986). Many researches have demonstrated that fish species living in low oxygen concentration sites show greater blood affinity to this gas than those living in well oxygenated sites (Johansen et al., 1978a,b; Powers et al., 1979a,b; Powers, 1985; Val et al., 1986, 1990). 


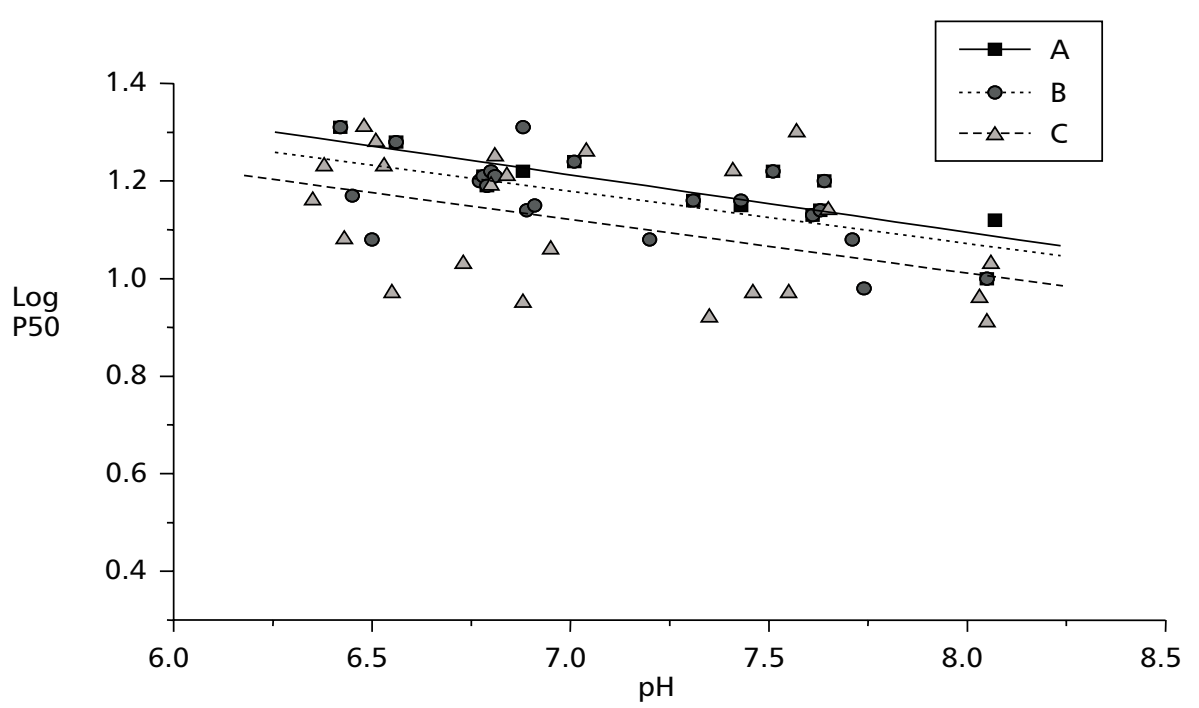

Fig. 2 - Hemoglobin oxygen equilibria in blood: $\mathrm{P} 50 \mathrm{XpH}$ from Astyanax scabripinnis at $20^{\circ} \mathrm{C}$. A. 1,920 m, B. $1,800 \mathrm{~m}$, and C. $700 \mathrm{~m}$.

TABLE 2

The Root effect in the presence and absence of phosphates (ATP and GTP).

\begin{tabular}{|l|c|c|}
\hline \multicolumn{1}{|c|}{ Hb } & \% deoxygenation & Farmer \\
\hline Stripped & 12 & + \\
\hline Stripped + ATP & 22 & ++ \\
\hline Stripped + GTP & 34 & ++ \\
\hline
\end{tabular}

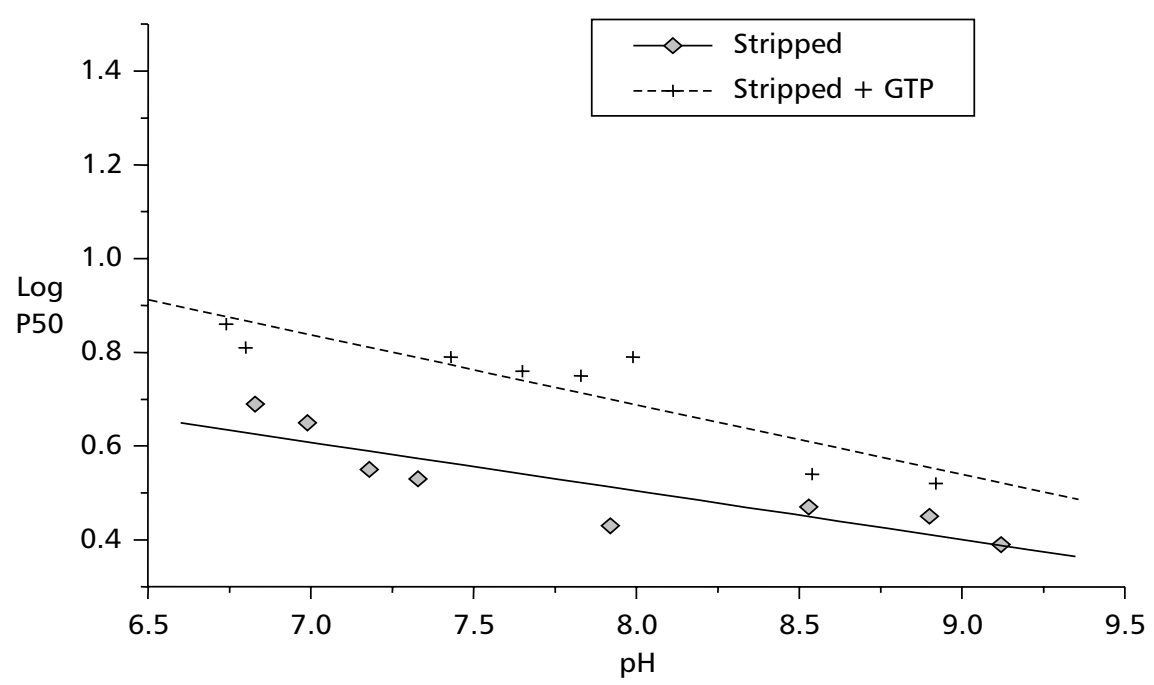

Fig. 3 - The $\mathrm{pH}$ effect on oxygen affinity of stripped hemoglobin from A. scabripinnis in the presence and absence of GTP at $20^{\circ} \mathrm{C}$. 
The data obtained on oxygen affinities and their $\mathrm{pH}$ dependence from unfractionated blood of Astyanax scabripinnis in three studied altitudes showed normal Bohr effect. This is positive for these fishes, since it facilitates $\mathrm{O}_{2}$ release at the tissular level and uptake by the gills. However the data obtained on blood- $\mathrm{O}_{2}$ affinity shows slight differences depending on the altitude at which the sample was obtained (Table 1).

The different $\mathrm{O}_{2}$ affinities in individuals caught at the three altitudes, can be due to oxygen availability and/or water temperature. At low altitudes $(700 \mathrm{~m})$ the water is warmer and oxygen concentration lower than at the others $(1,800$ and $1,920 \mathrm{~m}$ ) (Table 1).

The hemoglobin $\mathrm{Hb}-\mathrm{O}_{2}$ affinity of vertebrates is regulated by allosteric effectors, such as chlorides $\left(\mathrm{Cl}^{-}\right)$, protons $\left(\mathrm{H}^{+}\right)$, carbon dioxide $\left(\mathrm{CO}_{2}\right)$, and several types of organic phosphates, besides temperature and salinity (reviewed by Weber \& Jansen, 1988). In general, the increase of any of these factors or physical parameters within erythrocytes causes a drop in $\mathrm{Hb}-\mathrm{O}_{2}$ affinity.

Acknowledgments - We are thankful to Prof. Orlando Moreira Filho, Flavia Munin, Simoni S. Reinoso and the technician Luís Henrique da Silva (Piau) for helping to catch the fishes. G. F. L., holds a fellowship from FAPESP. Thanks are also due to Paula Matvienko-Sikar, who reviewed the manuscript. This work was supported by CNPq, FAPESP and CAPES.

\section{REFERENCES}

FARMER, M., FYHNS, H. J., FYHN, U. E. H. \& NOBLE, E. W., 1979, Occurrence of Root effect hemoglobins in Amazoniam fishes. Comp. Biochem. Physiol., 62A: 115-124.

GREANEY, G. S. \& POWERS, D. A., 1978, Allosteric modifiers of fish hemoglobins: "in vitro" and "in vivo" studies of effect of ambient oxygen and $\mathrm{pH}$ on the erytrocyte ATP concentrations. J. Exp. Zool., 203: 339-350.

JOHANSEN, K., MANGUN, C. P. \& WEBER, R. E., 1978a, Reduced blood oxygen affinity associated with airbreathing in fishes. Can. J. Zool., 56: 891-897.

JOHANSEN, K., MANGUN, C. P. \& LYKKEBOE, G., 1978b, Respiratory properties of the blood of Amazonian fishes. Can. J. Zool., 56: 898-906.

KROGH, A. \& LEITCH, J., 1911, The respiratory function of the blood in fishes. J. Physiol., 52: 288-300.

POWERS, D. A., 1974, Struture, function and molecular ecology of fish hemoglobins. Ann. N. Y. Acad. Sci., 241: 472-492.
POWERS, D. A., FYHN, H. J., FYHN, U. F. H., MARTIN, J. F., GARLICK, R. L. \& WOOD, S. C., 1979a, A comparative study of the oxygen equilibria of blood from 40 genera of amazonian fishes. Comp. Biochem. Physiol., 62A: $67-87$.

POWERS, D. A., MARTIN, J. P., GARLICK, R. L. \& FYHN, H. J., 1979b, The effect of the temperature of oxygen equilibria of fish hemoglobin in relation to the environmental thermal variability. Comp. Biochem. Physiol., 62A: 87-94.

POWERS, D. A., 1985, Molecular and cellular adaptations of fish hemoglobins - oxygen affinity to environmental changes. In: J. Lamy, J. P. Truchot \& R. Gilles (eds.), Respiratory pigments in animals, relations structurefunction. Spring-Verlag, Berlim-Heidelberg-Germany, pp. 97-124.

RIGGS, A. \& WOLBACH, R. A., 1956, Sulphydryl groups and the structure of hemoglobin. J. Gen. Physiol., 39: 585-605.

RIGGS, A., 1979, Studies of the hemoglobins of Amazonian fishes. An overview. Comp. Biochem. Physiol., 62A: 257272.

SCHWANTES, A. R., SCHWANTES, M. L. B., BONAVENTURA, C., SULLIVAN, B. \& BONAVENTURA, J., 1976, Hemoglobins of Boa constrictor amarali. Comp. Biochem. Physiol., 54B: 447-450.

SMITHIES, O., 1955, Zone electrophoresis in starch gels: group variations in the serum proteins of normal adults. Biochem. J., 61: 629-641.

SMITHIES, O., 1959, An improved procedure for starch gel electrophoresis. Biochem. J., 71: 585-587.

VAL, A. L., SCHWANTES, A. R., SCWHANTES, M. L. B. \& DE LUCA, P. H., 1981, Amido hidrolizado de milho como suporte eletroforético. Ciência e Cultura, 33: 992996

VAL, A. L., SCHWANTES, A. R. \& ALMEIDA-VAL, V. M. F., 1986, Biological aspects of Amazonian fishes. IV. Hemoglobins and whole blood properties of Semaprochilodus species (Prochilodontidae) at two phases of migration. Comp. Biochem. Physiol., 83B: 659-667.

VAL, A. L., ALMEIDA-VAL, V. M. F. \& AFFONSO, E. G., 1990, Adaptative features of amazon fishes: hemoglobins, hematology, intraerythrocytic phosphates and whole blood Bohr effect of Pterygoplichthys multiradiatus (Siluriformes). Comp. Biochem. Physiol., 97B: 852-855.

WEBER, R. E., WOOD, S. C. \& DAVIS, J. C., 1979, Acclimation to hypoxic water in facultative air-breathing fish: blood oxygen affinity and allosteric effectors. Comp. Biochem. Physiol., 62A: 125-130.

WOOD, S. C. \& JOHANSEN, K., 1972, Adaptation to hipoxia by increased $\mathrm{Hb}-\mathrm{O}_{2}$ affinity and decreased red cell ATP concentration. Nature, 237: 278-279. 